\title{
Erratum to: The Molecular Basis of Evolution and Disease: A Cold War Alliance
}

\author{
Edna Suárez-Díaz ${ }^{1}$ \\ Published online: 10 May 2017 \\ (C) Springer Science+Business Media Dordrecht 2017
}

\section{Erratum to: Journal of the History of Biology https://doi.org/10.1007/s10739-017-9476-9}

The original version of this article was revised: English possessives with apostrophe mark, like Beatty's or Paul's, were erroneously transformed and written as letters with a Spanish accentuation mark (e.g. Beattýs, Pauĺs).

The online version of the original article can be found under https://doi.org/10.1007/s10739-017-9476-9.

Edna Suárez-Díaz

ednasuarez@ciencias.unam.mx

1 Departamento de Biología Evolutiva, Facultad de Ciencias, Universidad Nacional Autónoma de México (UNAM), Av. Universidad 3000 Copilco, Coyoacán, 04510 Mexico City, Mexico 